\title{
Pengaruh Lingkungan Kerja dan Disiplin Kerja Terhadap Kinerja Karyawan Pada Indomaret Cabang Kelapa Dua Gading Serpong Kabupaten Tangerang
}

\author{
Darmadi* \\ *Universitas Pamulang. Email : dosen02445@unpam.ac.id
}

\section{ARTICLES INFORMATION}

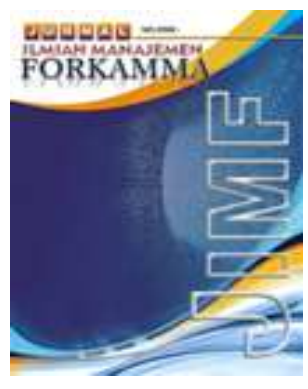

\section{JURNAL ILMIAH MANAJEMEN FORKAMMA}

Vol.3, No.3, Juli 2020

Halaman : $240-247$

(c) LPPM \& FORKAMMA

Prodi Magister Manajemen UNVERSITAS PAMULANG

ISSN (online) : 2599-171X

ISSN (print) : : 2598-9545

\section{Keyword :}

Lingkungan Kerja; Disiplin Kerja; Kinerja Karyawan.

JEL. classification : A11, L22, M31

\section{Contact Author : \\ PRODI \\ MAGISTER MANAJEMEN \& FORKAMMA UNPAM \\ JL.Surya Kencana No.1 Pamulang \\ Tangerang Selatan - Banten \\ Telp. (021) 7412566, Fax (021) 7412491 \\ Email : \\ jurnalforkamma.unpam@gmail.com}

\begin{abstract}
Maksud dari penelitian ini ialah untuk mengetahui dampak lingkungan kerja dan disiplin kerja terhadap produktivitas karyawan. Metode ini digunakan metode penelitian asosiatif. "Dalam penelitian ini adalah karyawan Indomaret Cabang Kelapa Dua Gading serpong 120 res.pon.den Metode pengumpulan data dan metode analisis data untuk instrumentasi, asumsi klasik, regresi linier berganda, koefisien korelasi, koefisien determinasi uji-t dan uji-F, Hasil penelitian menunjukkan bahwa manajemen lingkungan kerja memiliki pengaruh positif dan signifikan terhadap produktivitas karyawan ketika jumlah mereka adalah 4,019> t Tabel pada tahun 1984 dengan signifikan 0,000 <0,05, Disiplin kerja parsial memiliki dampak positif dan signifikan terhadap kinerja karyawan ketika 4,011> 1,984 dengan nilai signifikan 0,000 $<0,05$, Lingkungan kerja dan disiplin kerja memiliki dampak positif dan signifikan terhadap kinerja karyawan dengan nilai Fcount 20,529> Ftable 3,07 dengan nilai 0,000 <0,05".
\end{abstract}

The purpose of this study is to determine the impact of the work environment and work discipline on employee productivity. This method is used associative research methods. In this study Indomaret Kelapa Dua Gading serpong employees, "120 res.pon.den Data collection methods and data analysis methods for instrumentation, classical assumptions, multiple linear regression, correlation coefficient, coefficient of determination, $t$-test and F-test". "The results showed that the management of the work environment had a positive and significant effect on employee productivity when their number was 4,019> $t$, Table in 1984 with a significant 0,000 <0.05, Partial work discipline had a positive and significant impact on employee performance when 4,011> 1,984 with a significant value of $0,000<0.05$ ". The work environment and work discipline have a positive and significant impact on employee performance with a value of Fcount 20,529> Ftable 3.07 with a value of $0,000<0.05$. 


\section{A. PENDAHULUAN} \\ ISSN (print) : 2598-9545 \& ISSN (online) : 2599-171X}

Kinerja memainkan peran penting dalam perusahaan, kinerja adalah hasil dari karyawan menyelesaikan tugas mereka. Karyawan yang menyelesaikan tugasnya dengan benar akan memiliki kinerja tinggi.

Indomaret cabang kelapa dua gading serpong kabupaten tangerang adalah Mini market yang menyediakan kebutuhan sembako dan kebutuhan rumah tangga. Indomaret merupakan pioneer yang memperkenalkan cara berbelanja produk rumah tangga dengan konsep one stop shooping, dimana orang dapat berbelanja segala kebutuhan rumah tangga, lengkap, nyaman dan harga relatif murah dengan kualitas terjamin.

Dalam upaya meningkatkan Keuntungan dengan baik maka diperlukan SDM yang mampu bekerja secara optimal, maka dari itu Indomaret cabang kelapa dua gading serpong kabupaten tangerang melakukan penilaian kinerja karyawan untuk mengetahui dan mengukur kinerja karyawan. Penilaian kinerja ini dilakukan secara periodik setiap satu tahunnya untuk mengetahui pencapaian kemajuan kinerja seluruh karyawan. Kualitas kerja karyawan dapat diukur dengan penilaian perilaku kinerja karyawan.

Melihat kondisi lingkungan kerja di Indomaret cabang kelapa dua gading serpong kabupaten tangerang ditemukanya masalah jarak koputitor dekat saling berhadapan atau berdampingan, lahan parkir tidak luas dan ada toko tidak ada tempat duduk bagi kastamer yang mau makan dan minum diindomaret. Permasalahan disiplin kerja indomaret cabang kelapa dua gading serpong kabupaten tangerang ditemukan permasalahan terkait Kurang disiplin karyawan pada cabang kelapa dua gading serpong kabupaten tangerang seperti: karyawan sering libur diluar hari libur yang telah ditetapkan perusahaan (karyawan membolos). "Karyawan tidak menaati jam kerja yang ditetapkan perusahaan seperti datang kerja terlambat, karyawan tidak menaati peraturan tertulis yang berlaku. Karyawan banyak mengobrol pada saat jam kerja serta tidak menginformasikan kepada atasan ketika tidak masuk kerja". Beberapa kali, ia menemukan bahwa karyawan tidak bertugas selama jam kerja, beberapa karyawan merasa lelah, bosan dan tertekan di tempat kerja. Ada karyawan yang masih beredar selama jam kerja, tidak terkait dengan bekerja selama jam kerja atau yang meninggalkan tempat kerja hanya untuk merokok. Ini adalah salah satu masalah tingkat rendahpegawai dari segi kedisiplinan

Berdasarkan latar belakang masalah, penulis merasa perlu melakukan penelitian pengaruh lingkungan kerja dan disiplin kerja terhadap kinerja Karyawan Pada Indomaret cabang kelapa dua gading serpong kabupaten tangerang.

\section{Rumusan Masalah}

a. Apakah lingkungan kerja berdampak positif dan signifikan terhadap kinerja karyawan Indomaret Cabang Kelapa Dua Gading Serpong Kabupaten Tangerang.?

b. Apakah disiplin kerja berdampak positif dan signifikan terhadap kinerja karyawan Indomaret Cabang Kelapa Dua Gading Serpong Kabupaten Tangerang.?

c. Apakah lingkungan kerja dan disiplin kerja secara simultan berpengaruh positif dan signifikan terhadap kinerja karyawan Indomaret Cabang Kelapa Dua Gading Serpong Kabupaten Tangerang.?

\section{Tujuan Penelitian}
a. Untuk mengetahui berdampak lingkungan kerja terhadap kinerja karyawan Indomaret Cabang Kelapa Dua Gading Serpong Kabupaten Tangerang,.
b. Untuk mengetahui berdampak disiplin kerja terhadap kinerja karyawan Indomaret Cabang Kelapa Dua Gading Serpong Kabupaten Tangerang,.
c. Untuk mengetahui berdampak lingkungan kerja dan disiplin kerja secara simultan terhadap kinerja karyawan Indomaret Cabang Kelapa Dua Gading Serpong Kabupaten Tangerang.




\section{B. KAJIAN LITERATUR}

\section{Lingkungan Kerja}

Menurut Sri Widodo (2016:95), "lingkungan kerja merupakan lingkungan dimana para karyawan dapat melaksanakan tugasnya sehari-hari dengan keseluruhan sarana dan prasarana kerja yang diperlukan untuk melaksanakan tugas-tugas tersebut, Menurut (Nitisemito dalam Nuraini 2013;97) linkungan kerja adalah segala sesuatu yang ada disekitar karyawan dan dapat mempengaruhi dalam menjalankan tugas yang diembankan kepadanya misalnya dengan adanya air conditioner (AC) penerangan yang memadai dan sebagainya Menurut (Simanjuntak, 2003:39) lingkungan kerja dapat diartikan sebagai keseluruhan alat perkakas yang dihadapi, lingkungan sekitarnya dimana seorang bekerja, metode kerjanya, sebagai pengaruh kerjanya baik sebagai perorangan maupun sebagai kelompok".

\section{Disiplin Kerja}

Hasibuan (2010:193), Mengngemukakan "disiplin kerja adalah kesadaran dan kesediaan seseorang menaati semuaperaturan perusahaan dan norma-norma sosial yang berlaku Kinerja memiliki peranan yang sangat penting dalam perusahaan karena kinerja merupakan bentuk hasil akhir dari proses pegawai menyelesaikan tugasnya, Menurut Rivai (2011) pengertian disiplin kerja adalah suatu alat yang dipergunakan para manajer untuk berkomunikasi dengan karyawan agar mereka bersedia untuk mengubah suatu perilaku serta sebagai suatu upaya untuk meningkatkan kesadaran dan kesediaan seorang dalam memenuhi segala peraturan perusahaan, Pendapat Harlie $(2010 ; 117)$ disiplin kerja pada hakekatnya adalah bagaimana menumbuhkan kesadaran bagi para pekerjanya untuk melakukan tugas yang telah diberikan, dan pembentukan disiplin kerja ini tidak timbul dengan sendirinya".

\section{Kinerja Karyawan}

Pendapat Mangkunegara (2008:67), "kinerja atau prestasi kerja adalah hasil kerja secara kualitas dan kuantitas yang dicapai oleh seorang pegawai dalam melaksanakan tugasnya sesuai dengan tanggung jawab yang diberikannya, Karyawan yang menyelesaikan tanggung jawabnya dengan benar akan memiliki kinerja tinggi. Menurut Hadari Nawawi $(2006$; 63) Kinerja dikatakan tinggi apabila suatu target kerja dapat diselesaikan pada waktu yang tepat atau tidak melampui batas waktu yang disediakan". Performa berkurang jika melebihi batas waktu yang disediakan atau menunda.

\section{Kerangka Berfikir}

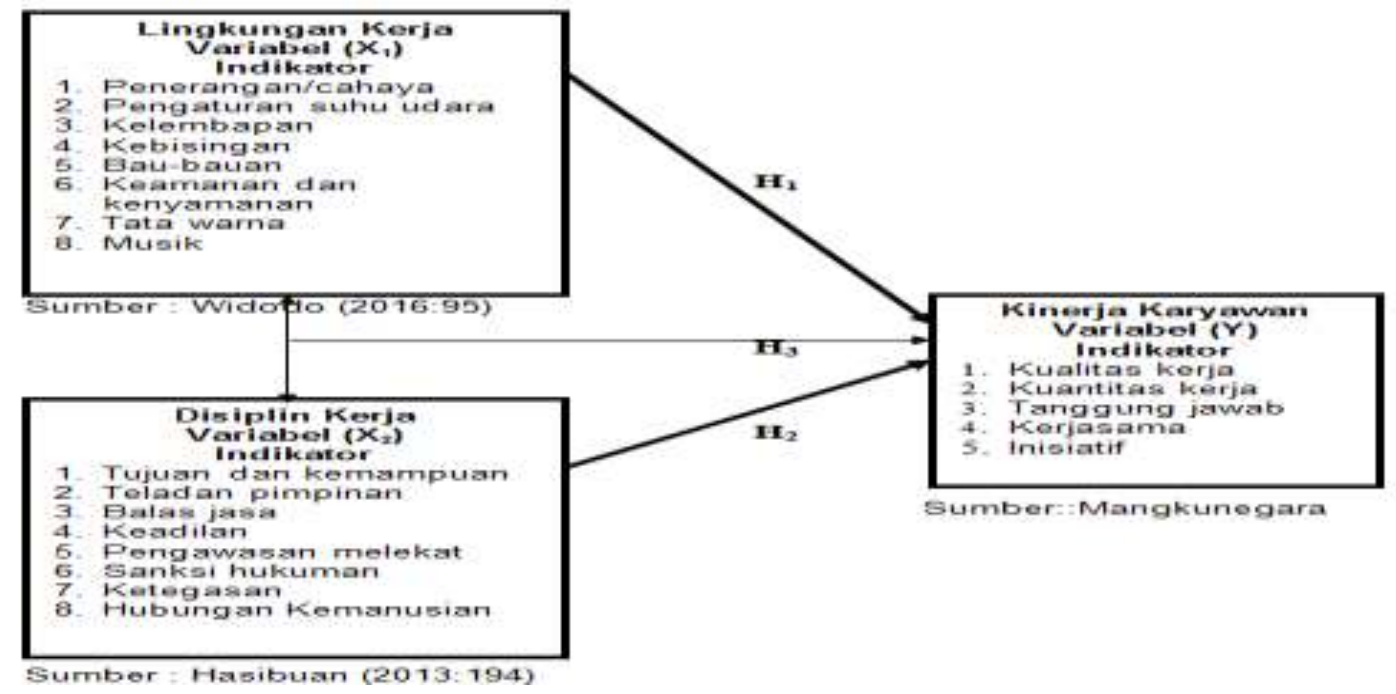

Gambar 1. Kerangka Berfikir 


\section{METODOLOGI PENELITIAN}

Tempat penelitian ini dilakukan pada Indomaret Cabang Kelapa Dua Gading Serpong Kabupaten Tangerang. Waktu penelitian Juni 2018 s/d Maret 2019 Jenis dalam penelitian ini yaitu penelitian kuantitatif. Sedangkan metode penelitian ini menggunakan metode Asosiatif, menurut "Sugiyono (2015:44) yaitu , penelitian yang bertujuan untuk mengetahui pengaruh atau hubungan antara dua variabel lebih".

\section{HASIL DAN PEMBAHASAN}

Berdasarkan hasil pengumpulan data primer dan sekunder,"gambaran umum hasil penelitian telah diperoleh. Data yang terkumpul kemudian diproses sesuai dengan jumlah peserta yang ditentukan sebelumnya, jumlah survei yang didistribusikan kepada para peserta adalah 120, dan semuanya telah dikembalikan". Setelah data survei dikumpulkan, ternyata memenuhi persyaratan analisis secara umum dan ditafsirkan untuk memecahkan masalah yang dirumuskan sebelumnya.

\section{Pengujian Instrumen}

\section{a.Uji Validitas}

Tabel 2. Hasil validasi

\begin{tabular}{|l|c|c|c|c|c|}
\hline Pernyataan & $\begin{array}{c}\text { Nilai } \mathbf{r} \\
\text { hitung }\end{array}$ & $\begin{array}{c}\text { Nilai } \mathbf{r} \\
\text { hitung }\end{array}$ & $\begin{array}{c}\text { Nilai } \mathbf{r} \\
\text { hitung }\end{array}$ & $\begin{array}{c}\text { Nilai } \mathbf{r} \\
\text { tabel }\end{array}$ & Keterangan \\
\hline P1 & 0.430 & 0.409 & 0.402 & 0,179 & Valid \\
\hline P2 & 0.396 & 0.460 & 0.477 & 0,179 & Valid \\
\hline P3 & 0.821 & 0.517 & 0.604 & 0,179 & Valid \\
\hline P4 & 0.605 & 0.535 & 0.575 & 0,179 & Valid \\
\hline P5 & 0.439 & 0.513 & 0.583 & 0,179 & Valid \\
\hline P6 & 0.277 & 0.555 & 0.470 & 0,179 & Valid \\
\hline P7 & 0.522 & 0.594 & 0.650 & 0,179 & Valid \\
\hline P8 & 0.597 & 0.618 & 0.540 & 0,179 & Valid \\
\hline P9 & 0.779 & 0.420 & 0.485 & 0,179 & Valid \\
\hline P10 & 0.789 & 0.630 & 0.375 & 0,179 & Valid \\
\hline
\end{tabular}

Sumber: Data diolah penulis (2019)

Menunjukkan total nilai $r$ lebih besar dari $r$ tabel $(0,179)$, sehingga semua butir pernyataan dalam variabel kinerja karyawan valid

\section{b. Uji Reliabilitas}

Tabel 3. Hasil uji reliabilitas

\begin{tabular}{|l|c|c|c|}
\hline \multicolumn{1}{|c|}{ Variabel } & $\begin{array}{c}\text { Crombach } \\
\text { Alpha }\end{array}$ & Kriteria & Keputusan \\
\hline Lingkungan Kerja $\left(\mathrm{X}_{1}\right)$ & 0,771 & $>0,60$ & Reliabel \\
\hline Dsiplin Kerja $\left(\mathrm{X}_{2}\right)$ & 0,710 & $>0,60$ & Reliabel \\
\hline Kinerja Karyawan $(\mathrm{Y})$ & 0,696 & $>0,60$ & Reliabel \\
\hline
\end{tabular}

Sumber: Data diolah penulis (2019)

Setiap variabel antara variabel $X 1, X$, dan $Y$ ternyata nilai Kronbach Alpha $\geq 0,60$. Dengan demikian, hasil uji reliabilitas untuk semua variabel dapat diandalkan. 


\section{Asumsi Klasik}

a. Uji Normalitas Data

Normal P-P Plot of Regression Standardized Residual

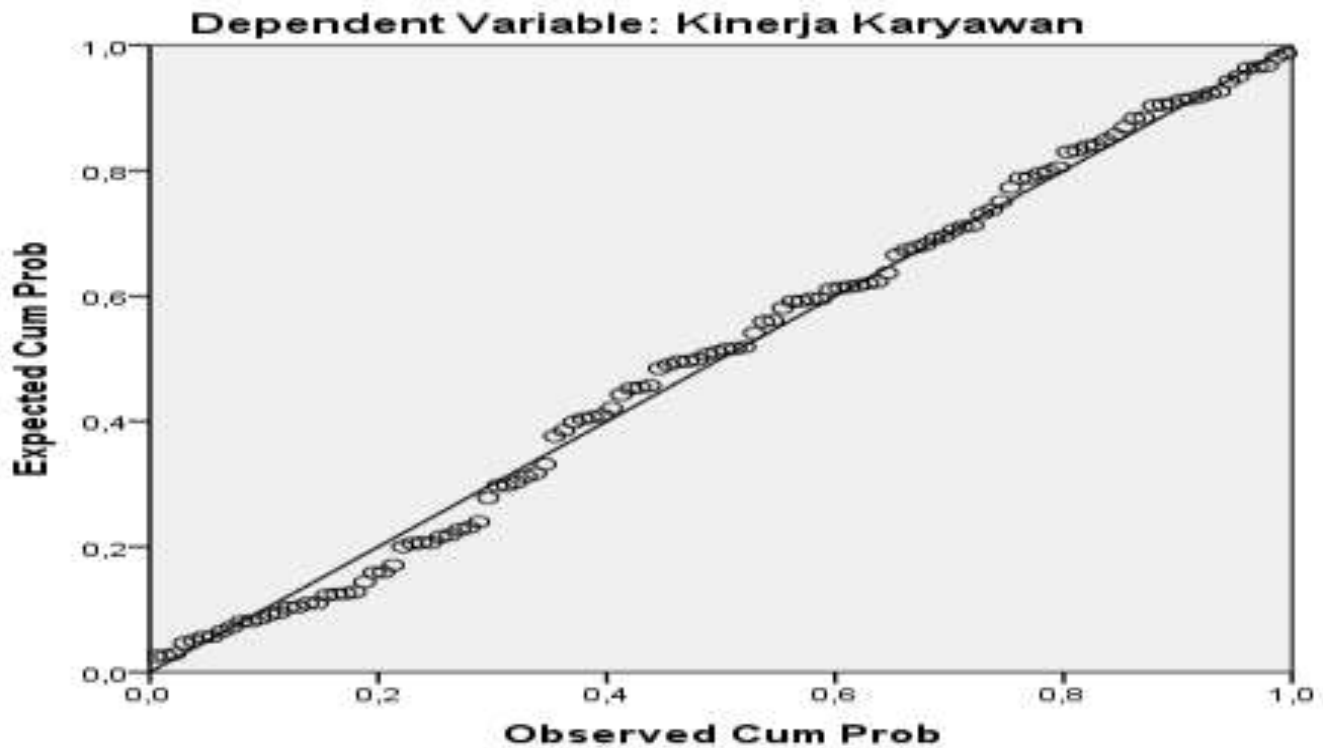

Sumber: Data diolah penulis (2019)

Gambar 2. Hasil uji normalitas data P.P Plot

Melihat diagram probabilitas normal di atas, dapat disimpulkan bahwa diagram probabilitas normal, sehingga dapat disimpulkan dapat diketahui penelitian ini berdistribusi normal.

\section{b. Uji Multikolineritas}

Tabel 4. Hasil uji multikolinearitas

\begin{tabular}{|ll|r|r|}
\hline \multirow{2}{*}{ Model } & \multicolumn{2}{|c|}{ Collinearity Statistics } \\
\cline { 2 - 3 } & Tolerance & \multicolumn{1}{c|}{ VIF } \\
\hline 1 (Constant) & & \\
& Lingkungan Kerja &, 961 & 1,040 \\
Disiplin Kerja &, 961 & 1,040 \\
\hline
\end{tabular}

a. Dependent Variable: Kinerja Karyawan

Sumber: Data diolah penulis (2019)

Nilai toleransi dan SWF untuk masing-masing variabel:

Nilai toleransi untuk variabel kontrol Lingkungan kerja (X1) adalah 0,961>0,10, berarti Variabel tidak terjadi dengan gejala multicolor.

Nilai toleransi variabel $(X 2)$ adalah $0,961>0,10$, yang berarti tidak terjadi korelasi 


\section{c. Uji Heteroskedastisitas}

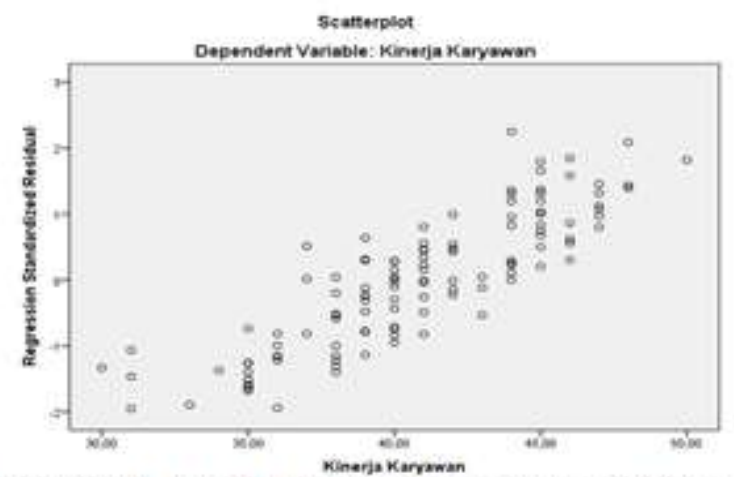

Gambar 3. Hasil ujian heteroskedastisitas

Sumber: Data diolah penulis (2019)

Titik-titik merambat tidak teratur, tidak membentuk pola yang jelas, dan merambat di atas dan di bawah angka 0 di sepanjang sumbu $Y$, sehingga tidak ada heterosadensitas.

\section{Uji Regresi Linier Berganda}

Tabel 5. Hasil regresi linier berganda

\begin{tabular}{|c|c|c|c|c|c|}
\hline \multirow[b]{2}{*}{ Model } & \multicolumn{2}{|c|}{$\begin{array}{c}\text { Unstandardized } \\
\text { Coefficients }\end{array}$} & \multirow{2}{*}{$\begin{array}{c}\text { Standardized } \\
\text { Coefficients } \\
\text { Beta }\end{array}$} & \multirow[b]{2}{*}{$\mathrm{t}$} & \multirow[b]{2}{*}{ Sig. } \\
\hline & B & $\begin{array}{l}\text { Std. } \\
\text { Error }\end{array}$ & & & \\
\hline 1 (Constant) & 17,498 & 3,652 & & 4,791 &, 000 \\
\hline $\begin{array}{l}\text { Lingkungan } \\
\text { Kerja }\end{array}$ &, 285 &, 071 & ,326 & 4,019 &, 000 \\
\hline Disiplin Kerja & 305 &, 074 & 333 & 4,101 &, 000 \\
\hline
\end{tabular}

a. Dependent Variable: Kinerja Karyawan

Sumber: Data diolah penulis (2019)

Diperoleh persamaan regresi linier berganda sebagai berikut $\mathrm{Y}=$ $17,498+0,285 \mathrm{X}_{1}+0,305 \mathrm{X}_{2}$

a. Nilai konstanta sebesar 17,498 variabel kepemimpinan transformasional $\left(X_{1}\right)$ dan motivasi kerja $\left(\mathrm{X}_{2}\right)$ dalam keadaan konstan, maka kinerja karyawan $(\mathrm{Y})$ adalah sebesar 17,498 .

b. Nilai regresi $0,285 X_{1}$ variabel kepemimpinan transformasional $\left(X_{1}\right)$ meningkat 1 satuan dengan asumsi variabel motivasi kerja $\left(\mathrm{X}_{2}\right)$ tetap, maka kinerja karyawan $(\mathrm{Y})$ akan meningkat sebesar 0,285 satuan.

c. Nilai regresi $0,305 X_{2}$ variabel motivasi kerja $\left(X_{2}\right)$ meningkat 1 satuan, dengan asumsi variabel kepemimpinan transformasional $\left(X_{1}\right)$ tetap, maka kinerja karyawan $(Y)$ akan meningkat sebesar 0,305 satuan. 


\section{Uji Koefisien Determinasi}

Tabel 6. Hasil defisien determinasi lingkungan kerja dan disiplin kerja terhadap Kinerja

\begin{tabular}{|l|l|r|r|c|}
\hline Model & R & R Square & $\begin{array}{c}\text { Adjusted R } \\
\text { Square }\end{array}$ & $\begin{array}{c}\text { Std. Error of the } \\
\text { Estimate }\end{array}$ \\
\hline 1 &, $510^{\mathrm{a}}$ &, 260 &, 247 & 3,65475 \\
\hline
\end{tabular}

a. Predictors: (Constant), Disiplin Kerja, Lingkungan Kerja

b. Dependent Variable: Kinerja Karyawan

Sumber: Data diolah penulis (2019)

Dapat diketahui bahwa Kepemimpinan Transformasional $\left(X_{1}\right)$ dan motivasi kerja $\left(X_{2}\right)$ memberikan kontribusi terhadap variabel kinerja karyawan $(Y)$ sebesar $26 \%$, sedangkan sisanya sebesar $74 \%$ di pengaruhi oleh variabel lain yang tidak diteliti dalam penelitian ini.

\section{Uji Hipotesis}

\section{a. Uji Hipotesis I}

1. $T$ hitung Lingkungan Kinerja $(X 1)$ adalah 4,019> t tabel 1,984 (lampiran) menunjukkan bahwa Lingkungan kinerja (X1) memiliki pengaruh positif dan signifikan terhadap kinerja karyawan (Y) pada Lingkungan kerja.

2. Nilai Disiplin kerja (X2) sebesar 4,101>t tabel 1,984 (terlampir) menunjukkan (X2) memiliki pengaruh positif. dan $(Y)$ pada Indomaret

\section{Uji Hipotesis Simultan atau uji F}

\section{Tabel 7. Hasil uji F hitung}

\begin{tabular}{|l|r|r|r|r|l|}
\hline Model & \multicolumn{1}{|c|}{$\begin{array}{c}\text { Sum of } \\
\text { Squares }\end{array}$} & \multicolumn{1}{c|}{ df } & \multicolumn{1}{c|}{$\begin{array}{c}\text { Mean } \\
\text { Square }\end{array}$} & \multicolumn{1}{c|}{$\mathrm{F}$} & Sig. \\
\hline 1 Regression & 548,409 & 2 & 274,204 & 20,529 &, $000^{\mathrm{b}}$ \\
Residual & 1562,791 & 117 & 13,357 & & \\
$\quad$ Total & 2111,200 & 119 & & & \\
\hline
\end{tabular}

a. Dependent Variable: Kinerja Karyawan

b. Predictors: (Constant), Disiplin Kerja, Lingkungan Kerja Sumber: Data diolah penulis (2019)

Hasil estimasi F hitung sebesar 20,529 tingkat signifikansi sebesar $0,000<0,05$. Sedangkan nilai $F$ tabel sebesar 3,07 (dari perhitungan $\mathrm{df}=2=0,05 \mathrm{dan} \mathrm{dk}=120-2$ $1=117$ diperoleh $F$ tabel 3,07). Ini berarti nilai Fhitung 20,529> Ftabel 3,07 con originine originaria $0,000<0,05$ con artinya Lingkungan kerja (X1) Disiplin Kerja (X2) Indomaret

\section{E. SIMPULAN}

\section{Kesimpulan}

a. Memberikan pengaruh positif dan signifikan (X1) pada (X2) di Indomaret Cabang Kelapa dua Kabupaten Tangerang. Dapat ditunjukkan dengan nilai regresi yang diperoleh, yaitu $Y=17.498+0.285 X$, nilai koefisien korelasi 0.326 , koefisien determinasi $15.3 \%$ dan nilai hitung $4.019>$ t tabel 1.998 (terlampir) dengan signifikan $0,000<0,05$. 
Ada pengaruh positif dan signifikan Disiplin kerja terhadap kinerja karyawan di Indomaret Cabang Kelapa dua Kabupaten Tangerang. Hal ini nilai regresi yang diperoleh $Y=17,498$ $+0,305 \times$ nilai koefisien korelasi 0,333 , koefisien determinasi $15,8 \%$ dan nilai thitung $4,101>$ ttabel 1,998 dengan signifikan $0,000<0,05$.

a. Secara bersama-sama terdapat pengaruh yang positif dan signifikan Lingkungan Kerja dan Disiplin kerja terhadap kinerja karyawan pada Indomaret Cabang Kelapa dua Kabupaten Jangerang. Persamaan regresi linier berganda, $Y=17.498+$ $0.285 \mathrm{X} 1+0.305 \mathrm{X} 2$, koefisien korelasi adalah 0.510 , koefisien determinasi adalah $26 \%$ dan nilai $F$ yang dihitung adalah $20.529>$ Ftable 3.07 dengan signifikan 0,000 $<0,05$.

\section{DAFTAR PUSTAKA}

\section{Sumber Buku}

Arif. Ramdhani 2011. Penilaian Kinerja. PT. Sarana Panca Karya Nusa.

Arikunto, Suharsimi. 2011. Prosedur Penelitian: Suatu Pendekatan Praktik. Edisi Revisi VII. Jakarta: PT. Rineka Cipta.

Ghozali, Imam, 2012, Aplikasi Analisis Multivariate dengan Program IBM SPSS. Universitas Diponegoro, Semarang

Hasibuan, Malayu. 2010. Manajemen Sumber Daya Manusia. Jakarta: PT Bumi Aksara.o

Hakim, L., Sunardi, N. (2017). Determinant of leverage and it's implication on company value of real estate and property sector listing in IDX period of 2011-2015. Man in India, 97(24), pp. 131-148

Mangkunegara, Anwar Prabu. 2008. Perencanaan dan Pengembangan Sumber Daya Manusia. Bandung: RFLIKA ADITAMA

Nawawi, Hadari. (2006). Evaluasi dan manajemen kinerja di lingkungan perusahaan dan industri. Yogyakarta: Gadjah Mada Univercity Press.

Rivai, Veithzal. 2011, Manajemen Sumber Daya Manusia untuk Perusahaan: dari Teori ke Praktik, Jakarta : RajaGrafindo Persada

Simanjuntak, Payaman. J. 2003. Pengantar Ekonomi Sumber Daya Manusia. Jakarta:Lembaga Penerbit Fakultas Ekonomi UI

Sri, Widodo Soedarso, 2015, Manajemen Sumberdaya Manusia : teori, prencanaan sttrategi, isu-isu utama dan globalisasi. Manggu Media, Bandung

Nardi Sunardi, E. A., Kadim, A., Tumanggor, M., \& Oktrima, B. (2018). Effects Of The Bank Soundness With The Rbbr Approach (Risk Base Bank Rating) Of Cost Efficiency And Its Implications On Sharia Bank Performance In Indonesia For The Period Of 2012-2016. International Journal of Economic Research, 15(1).

Sugiyono, 2015, Metode Penelitian Manajemen, CV Alvabeta, Bandung

Wardiyanto dan M.Baiquni. 2011. Perencanaan Pengembangan Pariwisata. Bandung: Lubuk Agung.

\section{Sumber Jurnal}

Harlie, M. 2010. "Pengaruh Disiplin kerja, Motivasi dan Pengembangan Karier Terhadap Kinerja Pegawai Negeri Sipil Pada Pemerintah Kabupaten Tabalong di Tanjung Kalimantan Selatan". Jurnal Manajemen dan Akuntansi.Vol. 11 No. 2, Oktober 2010; 117124. 